\title{
Layanan Bimbingan Kelompok Dengan Penggunaan Permainan "I've Got You" di SMA Negeri 1 Kurun, Kuala Kurun
}

Oleh: Oktamia Karuniawaty Sangalang ${ }^{1}, \mathrm{Mimi}^{2}, \mathrm{Nopi}^{3}$, Sunaryo A.I $\mathrm{I}^{4}$

Email: oktamia14@gmail.com; mimisuriatie84626@gmail.com;nopiferonika@gmail.com; sunarvo@fkip.upr.ac.id;

doi: https://doi.org/10.52850/ipn.v22i2.3494

History article

Accepted: 30 Desember $2021 \quad$ Published: December 2021

\begin{abstract}
Abstrak
Peran dan konstribusi guru sangat diharapkan guna kepentingan efektivitas dan efisien pelayanan Bimbingan dan Konseling di sekolah. Guru pun dapat bertindak sebagai konselor bagi siswanya. Tujuan pengabdian ini "ingin mengetahui partisipasi guru dalam melaksanakan layanan bimbingan kelompok dengan metode permainan "I've Got You” di Sekolah Menengah Atas Negeri 1 (SMAN-1) Kurun, Kuala Kurun, Kabupaten Kuala Kurun, Propinsi Kalimantan Tengah”. Sampel berjumlah 41 orang guru di SMAN-1 Kurun. Pengumpulan data menggunakan check list, berupa daftar pertanyaan-pertanyaan yang diberikan kepada guru-guru SMAN-1 Kurun. Cara menganalisa data untuk menguji kenyataan adanya partisipasi guru di sekolah terhadap pelaksanaan layanan bimbingan kelompok, pengabdi menggunakan perhitungan prosentase. Hasil pengabdian menunjukkan bahwa hampir seтиa komponen tujuan dalam pengabdian dilaksanakan dengan prosentase $100 \%$ tinggi oleh guru-guru di sekolah. Ini berarti guru sangat berpartisipasi dan mendukung Layanan Bimbingan Kelompok di SMAN-1 Kurun.
\end{abstract}

Kata Kunci : Konselor, Layanan Bimbingan Kelompok, Partisipasi Guru, Permainan "I've Got You"

\section{Group Guidance Services Using The Game "I've Got You" at SMA Negeri 1 Kurun, Kuala Kurun}

\begin{abstract}
The role and contribution of teachers is highly expected in the interest of the effectiveness and efficiency of Guidance and Counseling services in schools. Teachers can also act as counselors for their students. The purpose of this service is "to know the participation of teachers in implementing group guidance services with ${ }^{5}$ the "I've Got You" game method at Senior High
\end{abstract}

\footnotetext{
${ }^{1}$ Program Studi Pendidikan Bimbingan dan Konseling FKIP UPR

${ }^{2}$ Program Studi Pendidikan Bimbingan dan Konseling FKIP UPR

${ }^{3}$ Program Studi Pendidikan Bimbingan dan Konseling FKIP UPR

${ }^{4}$ Program Studi Pendidikan Bimbingan dan Konseling FKIP UPR
} 
School of Sekolah Menengah Atas Negeri-1 (SMAN-1) Kurun, Kuala Kurun, Kuala Kurun Regency, Central Kalimantan Province". The sample is 41 teachers at SMAN-1 Kurun. The data was collected using a check list, in the form of a list of questions given to the teachers of SMAN-1 Kurun. How to analyze data to test the reality of teacher participation in schools on the implementation of group guidance services, devotees use percentage calculations. The results of the service show that almost all components of the goals in service are carried out with a high percentage of $100 \%$ by teachers in schools. This means that teachers really participate and support the Group Guidance Service at SMAN-1 Kurun.

\section{Keywords: Conselor, Group Guidance Service, “I've Got You”games, Teacher Participation}

Permainan I've Got You adalah permainan yang membuat peserta gembira sambil berkenalan (Suwarjo \& Eliasa, 2011: 35). Bidang bimbingan dalam permainan I've got you adalah pribadi dan sosial. Waktu yang dipakai 30 menit. Bahan yang dipergunakan satu botol kosong. Berikut langkah-langkah permainan (Suwarjo \& Eliasa, 2011:35). Pertama, Duduklah di lantai dan membentuk suatu lingkaran, fasilitator meminta seorang sukarelawan untuk duduk di tengah-tengah lingkaran dan memutar botol yang pertama kali. Dia memberikan tugas pada siapapun yang ditunjuk botol kosong pada saat botol itu berhenti berputar. Misalnya dengan mengatakan : "siapapun yang ditunjuk botol ini harus bernyanyi potong bebek!". Tugas yang diberikan dapat beragam, Sesudah tugas tersebut dijalankan, peserta yang di tengah lingkaran pindah ke pinggir lingkaran dan digantikan oleh peserta yang baru saja ditunjuk botol. Jadi tugas sebagai pemutar botol berganti-ganti sampai semua peserta mendapat gilirannya. Nah, siapa yang akan mulai?”

Kedua, evaluasi dan refleksi (Suwarjo \& Eliasa, 2011: 36. Apa yang paling disukai dalam permainan tadi? Siapakah yang menjadi lebih dikenal sesudah permainan tadi? Apakah pada umumnya peserta senang bermain? Pertanyaan apa yang paling disukai? Apakah makna dari permainan ini? Ketiga, variasi (Suwarjo \& Eliasa, 2011: 36), permintaan kelompok dapat ditambahkan dengan : Menceritakan sesuatu yang lucu dari kehidupan dia; Menyebut 5 ekor binatang yang dimulai dengan huruf K; Melukiskan kampungnya dengan 5 kalimat; Meloncat 3 kali di atas kursi; Berpura-pura menjadi orang gembira sekali/ orang yang sedih/ berjualan di pasar dan sebagainya. Keempat, poin belajar (learning point) yang diperoleh (Suwarjo \& Eliasa, 2011:36) melalui berbagai pertanyaan dan diskusi, Konselor/guru Bimbingan dan 
Konseling/Fasilitator memfasilitasi peserta untuk menemukan poin poin belajar tentang bagaimana mengenal peserta lain dengan berbagai keadaan.

Sangalang dan Nopi (2016) meneliti pemberian bimbingan kelompok dengan menggunakan teknik musik dan permainan (games) untuk meningkatkan kecerdasan emosional siswa kelas X SMA Negeri 1 Palangka Raya. Penelitian ini mendukung dalam kegiatan pengabdian ini dan menjadi referensi layanan bimbingan kelompok dalam bimbingan dan konseling. Nazir (1983) membuktikan bahwa hasil penelitian kasus ini biasanya generalisasi dari pola-pola kasus yang tipikal dari individu, kelompok lembaga dan sebagainya. Djumhur dan Surya (1975) menyebutkan bimbingan sebagai proses bantuan terhadap individu untuk mencapai pemahaman diri yang dibutuhkan untuk melakukan penyesuaian diri secara maksimum di sekolah, keluarga dan masyarakat. Menurut Miller dan Mogdiliani (1961) menyatakan bahwa bimbingan merupakan proses bantuan terhadap individu untuk mencapai pemahaman diri dan pengarahan diri yang dibutuhkan untuk melakukan penyesuaian diri secara maksimum kepada sekolah (dalam hal ini termasuk madrasah), keluarga dan masyarakat.

Senjaya (2006: 342) menyebutkan salah satu peran yang dijalankan oleh guru yaitu sebagai pembimbing dan untuk menjadi pembimbing baik guru harus memiliki pemahaman tentang anak yang sedang dibimbingnya. Bahkan lebih khusus lagi guru wajib menjadi mitra dalam membantu menyukseskan program Bimbingan dan Konseling (BK) di sekolah. Memperhatikan pendapat di atas jelas memberi sinyal bahwa Program Bimbingan dan Konseling di sekolah merupakan bagian penting yang terintegrasi dan tidak bisa dipisahkan dengan program sekolah. Bimbingan dan Konseling akan bekerja sebagai suatu sistem dan bersinergi dengan komponen lainnya di sekolah seperti instruksional (pengajaran) dan Administrasi dan supervisi pendidikan. Ketiganya merupakan pilar untuk mengembangkan potensi siswa menurut Mortensen dan Schmuhler dalam Abimayu (1996: 221). Bahkan guru wajib membantu dan bekerjasama dalam melaksanakan program Bimbingan dan Konseling secara maksimal di sekolah. Dengan demikian untuk membantu proses pendidikan dan kwalitas manusia salah satu kebijaksanaan pemerintah adalah mengangkat bimbingan dan konseling di sekolah-sekolah sesuai dengan Surat Keputusan (SK) Menteri pada tanggal 15 Januari 1975 No. 008d/1975 dan 008e/1975, berikut dipertegas lagi dengan SK maupun No. 84/1993 dan No. 118/1996, dan terakhir terkandung dalam kurikulum 2013 adalah 
peminatan. Partisipasi sangatlah penting untuk mencapai tujuan bersama dalam suatu organisasi. Penulis melihat dalam program BK di Unit BK ada pembagian tugas pelayanan BK yang melibatkan guru di sekolah. Tetapi apakah tugas ini dilaksanakan dengan tugas dan tanggung jawab guru sebagai mitra program BK di SMA Negeri 1 Kurun, Kabupaten Kuala Kurun, Propinsi Kalimantan Tengah atau tidak terlaksana dengan baik oleh guru. Inilah yang menarik minat pengabdian lebih jauh tentang partisipasi guru dalam membantu pelaksanaan program Bimbingan dan Konseling di SMA Negeri 1 Kurun.

\section{Metode}

Alat pengumpulan data utama menggunakan teknik Check List, yaitu: suatu cara untuk memperoleh data dengan membuat daftar pertanyaan yang ditujukan kepada seluruh guru di sekolah pada SMA Negeri 1 Kurun. Pengumpulan data tentang penggunaan permainan I've Got Your melalui berbagai pertanyaan dan diskusi di dalam permainan yang sudah disiapkan, Konselor/guru Bimbingan dan Konseling/Fasilitator memfasilitasi peserta untuk menemukan poin-poin belajar tentang bagaimana mengenal peserta lain dengan berbagai keadaan pribadi dan sosial dari guru-guru di sekolah SMA Negeri 1 Kurun. Dalam melaksanakan pengabdian dengan Layanan Bimbingan Kelompok dengan penggunaan permainan I've Got You ini penulis mendapatkan gambaran Check List yang jawabnya tersedia dengan beberapa kemungkinan. Rerponden menjawab tinggal memilih salah satu dari kriteria jawaban yang ada pada Check List tersebut untuk menggali partisipasi guru di sekolah terhadap kegiatan bimbingan kelompok pada khusus dengan metode permainan "I've Got You”. Kriteria yang digunakan dalam mengambil kesimpulan adalah menggunakan angka seperti pada Tabel 1 beriku.

\section{Tabel 1. Kriteria jawaban Check List}

\begin{tabular}{|c|c|c|}
\hline Angka & Penjelasan & Prosentase $(\%$ \\
\hline 5 & Selalu & $81-100$ \\
\hline 4 & Sering & $51-80$ \\
\hline 3 & Kadang-kadang & $21-50$ \\
\hline 2 & Jarang sekali & $10-20$ \\
\hline 1 & Tidak pernah & $0-9$ \\
\hline
\end{tabular}

Teknik menganalisa dan membahas hasil pengabdian agar bersinergi dengan tujuan pengabdian, digunakan pula beberapa cara yaitu observasi, interview, dan dokumentasi. 
Observasi ialah suatu cara pengumpulan data dengan jalan melihat secara langsung pada tempat atau pada objek di tempat pengabdian. Dalam hubungan ini observasi dilakukan di SMA Negeri 1 Kurun. Observasi ini dilakukan dalam rangka mengamati partisipasi guru di sekolah dalam membantu program bimbingan dengan metode permainan "I've Got You" untuk memudahkan langkah pengabdian selanjutnya. Interview yaitu teknik pengumpulan data dengan mengadakan wawancara dengan guru di sekolah dan petugas Staf Sekolah serta tata usaha SMA Negeri 1 Kurun untuk memperjelaskan hasil Check List yang masih meragukan penulis dalam mengadakan pengabdian. Dokumentasi untuk mengetahui atau mempelajari tentang keadaan guru bidang studi dan bagaimana partisipasi mereka dalam membantu program Bimbingan Kelompok di SMA Negeri 1 Kurun. Pelaksanaan pengumpulan data. Check List yang sudah diuji coba, kemudian disusun kembali dan disebarkan kepada guru di sekolah yang telah dijadikan sampel dalam pengabdian ini. Dengan cara menghitung banyaknya dukungan responden terhadap masalah-masalah partisipasi guru di sekolah yang penulis jabarkan dalam pertanyaan-pertanyaan Check List.

\section{Hasil Pengabdian}

Penyajian data di bawah ini, berdasarkan hasil Check List yang sudah diedarkan kepada semua guru yang ada di SMA Negeri 1 Kurun. Hasil analisa data di bawah ini, maka diperoleh gambaran partisipasi guru di sekolah dalam membantu layanan bimbingan kelompok dengan permainan "I've Got You" di SMA Negeri 1 Kurun. Data tersebut disajikan Tabel 2.

Tabel 2. Prosentase jawaban responden dalam mengumpulkan data siswa untuk membantu petugas BK di sekolah

\begin{tabular}{llcc}
\hline No & Alternatif Jawaban & Frekuensi & Prosentase $(\%)$ \\
\hline a. & Selalu & 3 & 10,9 \\
b. & Sering kali & 3 & 21,7 \\
c. & Kadang-kadang & 34 & 54,3 \\
d. & Jarang sekali & 1 & 13,1 \\
e. & Tidak pernah & 0 & 0,0 \\
\hline & Jumlah & 41 & 100 \\
\hline
\end{tabular}

Dari hasil analisis dalam Tabel 2, diperoleh gambaran partisipasi guru di sekolah dalam membantu mengumpulkan data siswa, yang menjawab 'selalu' ada 3 orang (10,9 \%) dan 'sering kali' sebanyak 3 orang $(21,7 \%)$ serta 'kadang-kadang' ada 34 orang (54,3 \%), sedangkan yang menjawab 'jarang sekali' sebanyak 1 orang $(13,1 \%)$. 
Tabel 3. Prosentase jawaban responden dalam memperhatikan tingkah laku siswa di kelas

\begin{tabular}{llcc}
\hline No & Alternatif Jawaban & Frekuensi & Prosentase $(\%)$ \\
\hline a. & Selalu & 3 & 8,7 \\
b. & Sering kali & 3 & 28,3 \\
c. & Kadang-kadang & 34 & 58,7 \\
d. & Jarang sekali & 1 & 4,4 \\
e. & Tidak pernah & 0 & 0 \\
\hline & Jumlah & 41 & 100 \\
\hline
\end{tabular}

Berdasarkan Tabel 3 di atas dapat dilihat bahwa partisipasi guru di sekolah yang memperhatikan dan mengamati tingkah laku siswa di dalam kelas yang menjawab 'selalu' 3 orang $(8,7 \%)$ dan yang menjawab 'sering kali' sebanyak 3 orang $(28,3 \%)$, serta yang menjawab 'kadang-kadang' sebanyak 34 orang (58,7 \%), sedangkan 'jarang sekali' sebanyak 1 orang $(4,4 \%)$.

Tabel 4. Prosentase jawaban responden mengenal siswa-siswa yang memerlukan bantuan khusus

\begin{tabular}{llcc}
\hline No & Alternatif Jawaban & Frekuensi & Prosentase $(\%)$ \\
\hline a. & Selalu & 3 & 17,4 \\
b. & Sering kali & 3 & 26,1 \\
c. & Kadang-kadang & 34 & 47,7 \\
d. & Jarang sekali & 1 & 8,7 \\
e. & Tidak pernah & 0 & 0 \\
\hline & Jumlah & 41 & 100 \\
\hline
\end{tabular}

Dari Tabel 4 di atas dapat dilihat bahwa guru-guru kelas menjawab 'selalu' sebanyak 3 orang $(17,4 \%)$ dan yang 'sering kali' sebanyak 3 orang $(26,1 \%)$ serta yang 'kadangkadang' sebanyak 34 orang (47,7 \%), sedangkan yang menjawab 'jarang sekali' sebanyak 1 orang $(8,7 \%)$.

Pada Tabel 5 dapat diuraikan bahwa guru di sekolah yang menjawab selalu sebanyak 1 orang $(15,2 \%)$ dan yang menjawab sering kali sebanyak 5 orang $(21,7 \%)$ serta yang menjawab kadang-kadang-kadang sebanyak 34 orang (50\%) sedangkan yang menjawab jarang sekali sebanyak 1 orang $(13,1 \%)$.

Tabel 5. Prosentase jawaban responden dalam mencatat pribadi siswa yang mempunyai tingkah laku yang berlainan dengan siswa yang lain

\begin{tabular}{llcc}
\hline No & Alternatif Jawaban & Frekuensi & Prosentase $(\%)$ \\
\hline a. & Selalu & 1 & 15,2 \\
b. & Sering kali & 5 & 21,7 \\
c. & Kadang-kadang & 34 & 50 \\
d. & Jarang sekali & 1 & 13,1 \\
\hline
\end{tabular}




\begin{tabular}{llcc}
\hline e. & Tidak pernah & 0 & 0 \\
\hline & Jumlah & 41 & 100 \\
\hline
\end{tabular}

Tabel 6. Prosentase jawaban resonden dalam membantu menyelenggarakan bimbingan kelompok

\begin{tabular}{llcc}
\hline & Alternatif Jawaban & Frekuensi & Prosentase (\%) \\
\hline a. & Selalu & 0 & 0 \\
b. & Sering kali & 1 & 13 \\
c. & Kadang-kadang & 3 & 23,9 \\
d. & Jarang sekali & 34 & 43,5 \\
e. & Tidak pernah & 3 & 19,6 \\
\hline & Jumlah & 41 & 100 \\
\hline
\end{tabular}

Dalam Tabel 6 menunjukkan bahwa guru di sekolah menjawab 'selalu' tidak ada, sedangkan yang menjawab 'sering kali' sebanyak 1 orang (13\%) serta yang menjawab 'kadang-kadang' ada 3 orang (23,9 \%), yang menjawab 'jarang sekali' sebanyak 34 orang $(43,5 \%)$ dan yang 'tidak pernah' sebanyak 3 orang $(19,6 \%)$.

Tabel 7. Prosentase jawaban responden dalam bekerja sama dengan petugas bimbingan lainnya untuk membantu memecahkan masalah siswa

\begin{tabular}{|l|l|c|c|}
\hline No & Alternatif Jawaban & Frekuensi & Prosentase (\%) \\
\hline a. & Selalu & 1 & 4,3 \\
b. & Sering kali & 5 & 21,7 \\
c. & Kadang-kadang & 34 & 60,9 \\
d. & Jarang sekali & 1 & 13,1 \\
e. & Tidak pernah & 0 & 0 \\
\hline & Jumlah & 41 & 100 \\
\hline
\end{tabular}

Berdasarkan Tabel 7 di atas menunjukkan bahwa guru di sekolah yang menjawab 'selalu' hanya 1 orang $(4,3 \%)$ yang 'sering sekali' sebanyak 5 orang $(21,7 \%)$ dan yang 'kadang-kadang' sebanyak 34 orang (60,9\%), sedangkan yang 'jarang sekali' juga ada 1 orang $(13,1 \%)$.

Dalam Tabel 8 di atas ini dapat dilihat bahwa guru di sekolah yang menjawab tidak ada, yang menjawab sering kali 1 orang $(4,3 \%)$ serta yang kadang-kadang sebanyak 3 orang $(28,3 \%)$ sedangkan yang menjawab jarang sekali sebanyak 34 orang $(56,5 \%)$ yang tidak pernah sebanyak 3 orang yaitu $(10,9 \%)$.

Tabel 8. Prosentase jawaban responden mengenai kerjasama dengan petugas bimbingan dalam menyusun program BK di sekolah

\begin{tabular}{llcc}
\hline No & Alternatif Jawaban & Frekuensi & Prosentase $(\%)$ \\
\hline a. & Selalu & 0 & 0 \\
b. & Sering kali & 1 & 4,3 \\
c. & Kadang-kadang & 3 & 28,3 \\
d. & Jarang sekali & 34 & 56,5 \\
\hline
\end{tabular}




\begin{tabular}{llcc}
\hline e. & Tidak pernah & 3 & 10,9 \\
\hline Jumlah & 41 & 100 \\
\hline
\end{tabular}

Tabel 9. Prosentase jawaban responden dalam membantu memberikan layanan bimbingan preventif kepada siswa di sekolah

\begin{tabular}{llcc}
\hline No & Alternatif Jawaban & Frekuensi & Prosentase $(\%)$ \\
\hline a. & Selalu & 3 & 8,7 \\
b. & Sering kali & 3 & 15,2 \\
c. & Kadang-kadang & 34 & 73,9 \\
d. & Jarang sekali & 1 & 2,2 \\
e. & Tidak pernah & 0 & 0 \\
\hline & Jumlah & 41 & 100 \\
\hline
\end{tabular}

Dari Tabel 9 di atas dapat dilihat bahwa guru di sekolah menjawab 'selalu' sebanyak 3 orang $(8,7 \%)$, yang 'sering kali' sebanyak 3 orang $(15,2 \%)$ dan yang 'kadang-kadang' sebanyak 34 orang $(73,9 \%)$, serta yang menjawab 'jarang sekali' sebanyak 1 orang $(2,2 \%)$.

Tabel 10. Prosentase jawaban responden dalam memberikan layanan informasi kepada petugas bimbingan mengenai keadaan siswa

\begin{tabular}{llcc}
\hline No & Alternatif Jawaban & Frekuensi & Prosentase $(\%)$ \\
\hline a. & Selalu & 4 & 6,5 \\
b. & Sering kali & 3 & 82,6 \\
c. & Kadang-kadang & 34 & 10,9 \\
d. & Jarang sekali & 0 & 0 \\
e. & Tidak pernah & 0 & 0 \\
\hline & Jumlah & 41 & 100 \\
\hline
\end{tabular}

Dalam Tabel 10 di atas ini dapat dilihat bahwa guru-guru kelas menjawab 'selalu' sebanyak 4 orang $(6,5 \%)$ yang 'sering kali' sebanyak 3 orang $(82,6 \%)$ dan yang 'kadangkadang' sebanyak 34 orang (10,9\%), serta yang menjawab 'jarang sekali' dan 'tidak pernah' tidak ada.

Tabel 11. Prosentase jawaban responden dalam menyalurkan bakat, misalnya yang sesuai dengan kemampuan dan cita-cita siswa

\begin{tabular}{llcc}
\hline No & Alternatif Jawaban & Frekuensi & Prosentase $(\%)$ \\
\hline a. & Selalu & 1 & 4,3 \\
b. & Sering kali & 3 & 26,1 \\
c. & Kadang-kadang & 3 & 6,5 \\
d. & Jarang sekali & 34 & 63,1 \\
e. & Tidak pernah & 0 & 0 \\
\hline & Jumlah & 41 & 100 \\
\hline
\end{tabular}

Dari Tabel 11 di atas dapat dilihat bahwa guru di sekolah menjawab 'selalu' sebanyak 1 orang (4,3\%), yang menjawab 'sering kali' sebanyak 3 orang $(26,1 \%)$, yang menjawab 'kadang-kadang 'sebanyak 3 orang (6,5\%), dan menjawab 'jarang sekali' sebanyak 34 orang 
$(63,1 \%)$

Tabel 12. Prosentase jawaban responden dala mengikuti pertemuan dalam satu tahun untuk membicarakan peranan guru dalam membantu program BK

\begin{tabular}{llcc}
\hline No & Alternatif Jawaban & Frekuensi & Prosentase (\%) \\
\hline a. & Selalu & 0 & 0 \\
b. & Sering kali & 3 & 13,1 \\
c. & Kadang-kadang & 4 & 15,2 \\
d. & Jarang sekali & 34 & 71,7 \\
e. & Tidak pernah & 0 & 0 \\
\hline & Jumlah & 41 & 100 \\
\hline
\end{tabular}

Dari Tabel 12 di atas ini dapat dilihat bahwa guru di sekolah menjawab sering kali sebanyak 3 orang $(13,1 \%)$ yang kadang-kadang sebanyak 4 orang $(15,2 \%)$ yang menjawab jarang sekali sebanyak 34 orang $(71,7 \%)$.

Tabel 13. Prosentase jawaban responden dalam mengikuti untuk mengambil manfaat dari penataan (in-service-training) mengenai bimbingan

\begin{tabular}{llcc}
\hline No & Alternatif Jawaban & Frekuensi & Prosentase $(\%)$ \\
\hline a. & Selalu & 0 & 0 \\
b. & Sering kali & 0 & 0 \\
c. & Kadang-kadang & 7 & 47,8 \\
d. & Jarang sekali & 34 & 52,2 \\
e. & Tidak pernah & 0 & 0 \\
\hline & Jumlah & 41 & 100 \\
\hline
\end{tabular}

Dalam Tabel 13 di atas dapat dilihat bahwa guru di sekolah menjawab kadang-kadang sebanyak 7 orang $(47,8 \%)$ dan yang jarang sekali sebanyak 34 orang $(52,2 \%)$.

Tabel 14. Prosentase jawaban responden dalam mendapat pelajaran mengenai bimbingan

\begin{tabular}{llcc}
\hline No & Alternatif Jawaban & Frekuensi & Prosentase $(\%)$ \\
\hline a. & Selalu & 0 & 0 \\
b. & Sering kali & 3 & 15,2 \\
c. & Kadang-kadang & 4 & 28,3 \\
d. & Jarang sekali & 34 & 56,5 \\
e. & Tidak pernah & 0 & 0 \\
\hline & Jumlah & 41 & 100 \\
\hline
\end{tabular}

Berdasarkan Tabel 14 dapat dilihat bahwa guru di sekolah menjawab sering kali sebanyak 3 orang $(15,2 \%)$ sedangkan yang kadang-kadang sebanyak 4 orang $(28,3 \%)$ sedangkan yang menjawab jarang sekali sebanyak 34 orang $(56,5 \%)$. 
Tabel 15. Prosentase jawaban responden dalam melengkapi inventarisasi siswa dengan

\begin{tabular}{llcc} 
& \multicolumn{3}{c}{ data yang diperlukan } \\
\hline No & Alternatif Jawaban & Frekuensi & Prosentase (\%) \\
\hline a. & Selalu & 1 & 6,5 \\
b. & Sering kali & 3 & 19,6 \\
c. & Kadang-kadang & 34 & 47,8 \\
d. & Jarang sekali & 3 & 26,1 \\
e. & Tidak pernah & 0 & 0 \\
\hline & Jumlah & 41 & 100 \\
\hline
\end{tabular}

Dari Tabel 15 di atas ini dapat dilihat bahwa guru di sekolah menjawab selalu sebanyak 1 orang $(6,5 \%)$ yang menjawab sering kali sebanyak 3 orang $(19,6 \%)$ dan yang kadang-kadang sebanyak 34 orang $(47,8 \%)$ sedangkan yang menjawab jarang sekali sebanyak 3 orang $(26,1 \%)$.

Tabel 16. Prosentase jawaban responden dalam mengirimkan siswa-siswa mendatangi konselor agar siswa dapat bantuan tambahan

\begin{tabular}{|l|l|c|c|}
\hline No & Alternatif Jawaban & Frekuensi & Prosentase (\%) \\
\hline a. & Selalu & 0 & 0 \\
b. & Sering kali & 3 & 8,7 \\
c. & Kadang-kadang & 34 & 52,2 \\
d. & Jarang sekali & 4 & 39,1 \\
e. & Tidak pernah & 0 & 0 \\
\hline & Jumlah & 41 & 100 \\
\hline
\end{tabular}

Berdasarkan Tabel 16 di atas dapat dilihat bahwa guru di sekolah yang menjawab sering kali sebanyak 3 orang $(8,7 \%)$ yang menjawab kadang-kadang sebanyak 34 orang $(52,2 \%)$ dan yang jarang sekali 4 orang $(39,1 \%)$.

Tabel 17. Prosentase jawaban responden dalam menekankan implikasi kejujuran daripada mata pelajaran yang mereka berikan

\begin{tabular}{llcc}
\hline No & Alternatif Jawaban & Frekuensi & Prosentase (\%) \\
\hline a. & Selalu & 3 & 4,3 \\
b. & Sering kali & 4 & 34,8 \\
c. & Kadang-kadang & 34 & 60,9 \\
d. & Jarang sekali & 0 & 0 \\
e. & Tidak pernah & 0 & 0 \\
\hline & Jumlah & 41 & 100 \\
\hline
\end{tabular}

Dari Tabel 17 di atas ini dapat dilihat bahwa guru di sekolah menjawab selalu sebanyak 3 orang $(4,3 \%)$ yang menjawab sering kali sebanyak 4 orang $(34,8 \%)$ dan yang menjawab kadang-kadang sebanyak 34 orang $(60,9 \%)$. 
Tabel 18. Prosentase jawaban responden mengadakan "case studi" seorang siswa dan ikut serta dalam pembicaraan-pembicaraan dengan konselor dan guru-guru lainnya

\begin{tabular}{llcc}
\hline No & Alternatif Jawaban & Frekuensi & Prosentase (\%) \\
\hline a. & Selalu & 0 & 0 \\
b. & Sering kali & 3 & 17,4 \\
c. & Kadang-kadang & 4 & 30,4 \\
d. & Jarang sekali & 34 & 52,2 \\
e. & Tidak pernah & 0 & 0 \\
\hline & Jumlah & 41 & 100 \\
\hline
\end{tabular}

Berdasarkan Tabel 18 di atas dapat dilihat bahwa guru di Sekolah menjawab sering kali sebanyak 3 orang $(17,4 \%)$ yang menjawab kadang-kadang sebanyak 4 orang $(30,4 \%)$ dan yang jarang sekali sebanyak 34 orang $(52,2 \%)$.

Tabel 19. Prosentase jawaban responden dalam berusaha untuk saling tukar-menukar bahan informasi dengan konselor dan guru lain

\begin{tabular}{llcc}
\hline No & Alternatif Jawaban & Frekuensi & Prosentase $(\%)$ \\
\hline a. & Selalu & 0 & 0 \\
b. & Sering kali & 1 & 4,4 \\
c. & Kadang-kadang & 6 & 39,1 \\
d. & Jarang sekali & 34 & 56,5 \\
e. & Tidak pernah & 0 & 0 \\
\hline & Jumlah & 41 & 100 \\
\hline
\end{tabular}

Pada Tabel 19 di atas menunjukan bahwa guru-guru kelas yang menjawab sering kali sebanyak 1 orang $(4,4 \%)$ yang menjawab kadang-kadang sebanyak 6 orang $(39,1 \%)$ sedangkan yang menjawab jarang sekali sebanyak 34 orang $(56,5 \%)$.

Tabel 20. Prosentase jawaban responden memperkenalkan kepada siswa-siswa adanya pelayanan bimbingan di sekolah dan menganjurkan untuk memanfaatkannya

\begin{tabular}{llcc}
\hline No & Alternatif Jawaban & Frekuensi & Prosentase (\%) \\
\hline a. & Selalu & 1 & 4,4 \\
b. & Sering kali & 4 & 30,4 \\
c. & Kadang-kadang & 34 & 54,3 \\
d. & Jarang sekali & 2 & 10,9 \\
e. & Tidak pernah & 0 & 0 \\
\hline & Jumlah & 41 & 100 \\
\hline
\end{tabular}

Dalam Tabel 20 di atas dilihat bahwa guru-guru kelas yang menjawab selalu sebanyak 1 orang $(4,4 \%)$ yang menjawab sering kali sebanyak 4 orang $(30,4 \%)$ sedangkan yang kadang-kadang sebanyak 34 orang $(54,3 \%)$ dan yang menjawab jarang sekali sebanyak 2 orang $(10,9 \%)$. 
Tabel 21. Prosentase jawaban responden dalam menggunakan bahan-bahan bimbingan yang ada di perpustakaan

\begin{tabular}{llcc}
\hline No & Alternatif Jawaban & Frekuensi & Prosentase $(\%)$ \\
\hline a. & Selalu & 0 & 0 \\
b. & Sering kali & 0 & 0 \\
c. & Kadang-kadang & 4 & 10,9 \\
d. & Jarang sekali & 37 & 89,1 \\
e. & Tidak pernah & 0 & 0 \\
\hline & Jumlah & 41 & 100 \\
\hline
\end{tabular}

Dari Tabel 21 di atas ini dapat dilihat bahwa guru di sekolah menjawab kadangkadang sebanyak 4 orang (10,9\%) sedangkan yang menjawab jarang sekali sebanyak 37 orang $(89,1 \%)$.

Tabel 22. Prosentase jawaban responden berusaha mengarahkan siswa-siswa agar mencapai hasil individual pada setiap bidang studi semaksimal mungkin

\begin{tabular}{llcc}
\hline No & Alternatif Jawaban & Frekuensi & Prosentase (\%) \\
\hline a. & Selalu & 1 & 13 \\
b. & Sering kali & 3 & 41,3 \\
c. & Kadang-kadang & 36 & 26,1 \\
d. & Jarang sekali & 1 & 19,6 \\
e. & Tidak pernah & 0 & 0 \\
\hline & Jumlah & 41 & 100 \\
\hline
\end{tabular}

Berdasarkan Tabel 22 di atas ini dapat dianalisis bahwa guru di sekolah yang menjawab selalu sebanyak 1 orang (13\%) yang menjawab sering kali sebanyak 3 orang $(41,3$ $\%)$ sedangkan yang kadang-kadang sebanyak 36 orang $(26,1 \%)$ dan yang menjawab jarang sekali sebanyak 1 orang $(19,6 \%)$.

Tabel 23. Prosentase jawaban responden dalam memperhatikan siswa-siswa dan mengenal mereka dengan baik

\begin{tabular}{llcc}
\hline No & Alternatif Jawaban & Frekuensi & Prosentase (\%) \\
\hline a. & Selalu & 4 & 30,4 \\
b. & Sering kali & 36 & 65,2 \\
c. & Kadang-kadang & 1 & 4,4 \\
d. & Jarang sekali & 0 & 0 \\
e. & Tidak pernah & 0 & 0 \\
\hline & Jumlah & 41 & 100 \\
\hline
\end{tabular}

Dari Tabel 23 di atas ini dapat dilihat bahwa guru di sekolah menjawab yang selalu sebanyak 4 orang $(30,4 \%)$ yang menjawab sering kali sebanyak 36 orang $(65,2 \%)$ serta yang kadang-kadang sebanyak 1 orang $(4,4 \%)$. 
Tabel 24. Prosentase jawaban responden membantu siswa-siswa mengembangkan kebiasaan serta cara-cara belajar dan bekerja yang baik

\begin{tabular}{llcc}
\hline No & Alternatif Jawaban & Frekuensi & Prosentase $(\%)$ \\
\hline a. & Selalu & 0 & 0 \\
b. & Sering kali & 37 & 63,1 \\
c. & Kadang-kadang & 3 & 23,9 \\
d. & Jarang sekali & 1 & 13 \\
e. & Tidak pernah & 0 & 0 \\
\hline & Jumlah & 41 & 100 \\
\hline
\end{tabular}

Berdasarkan Tabel 24 di atas dapat kita lihat bahwa guru di sekolah yang menjawab sering kali sebanyak 37 orang $(63,1 \%)$ yang kadang-kadang sebanyak 3 orang $(23,9 \%)$ dan yang menjawab jarang sekali sebanyak 1 orang $(13 \%)$.

Tabel 25. Prosentase jawaban responden berusaha memperbincangkan perihal siswasiswa yang memerlukan perhatian khusus dengan kepala sekolah dan konselor

\begin{tabular}{llcc}
\hline No & Alternatif Jawaban & Frekuensi & Prosentase (\%) \\
\hline a. & Selalu & 0 & 0 \\
b. & Sering kali & 1 & 10,6 \\
c. & Kadang-kadang & 35 & 47,8 \\
d. & Jarang sekali & 3 & 23,9 \\
e. & Tidak pernah & 2 & 17,4 \\
\hline & Jumlah & 41 & 100 \\
\hline
\end{tabular}

Dalam Tabel 25 dapat dilihat bahwa guru di sekolah yang menjawab sering kali sebanyak 1 orang $(10,6 \%)$ yang menjawab kadang-kadang sebanyak 35 orang (47,8 \%) serta yang menjawab jarang sekali sebanyak 3 orang $(23,4 \%)$ dan tidak pernah sebanyak 2 orang $(17,4 \%)$.

Tabel 26. Prosentase jawaban responden bersama petugas BK di sekolah merundingkan masalah-masalah dan kebutuhan siswa-siswa dengan orang tua siswa

\begin{tabular}{llcc}
\hline No & Alternatif Jawaban & Frekuensi & Prosentase $(\%)$ \\
\hline a. & Selalu & 0 & 0 \\
b. & Sering kali & 1 & 6,6 \\
c. & Kadang-kadang & 4 & 21,7 \\
d. & Jarang sekali & 36 & 71,7 \\
e. & Tidak pernah & 0 & 0 \\
\hline & Jumlah & 41 & 100 \\
\hline
\end{tabular}

Dari Tabel 26 di atas ini dapat dilihat bahwa guru di sekolah menjawab yang sering kali sebanyak 1 orang $(6,6 \%)$ yang menjawab kadang-kadang sebanyak 4 orang $(21,7 \%)$ dan yang menjawab jarang sekali sebanyak 36 orang $(71,7 \%)$. 
Dari hasil pengabdian ini di dapat bahwa partisipasi guru di SMA Negeri 1 Kurun tinggi, dan pemanfaatan hasil permainan I've Got You adalah pada bidang pribadi dan sosial. Pemanfaatannya agar pada layanan bimbingan dan konseling selama ini bisa lebih menarik dan tidak membosankan dengan adanya permainan yang ditambahkan dalam setiap layanan, baik layanan bimbingan dan konseling, terkhusus pada layanan bimbingan kelompok bersifat pribadi siswa dan bisa bersosialisasi dengan teman sebayanya. Dapat juga memfasilitasi siswa memiliki kemampuan diri, rasa optimis, memiliki penilaian objektif, memiliki rasa tanggung jawab, memiliki cara berpikir rasional dan realistis yang baik terhadap suatu permasalahan yang dihadapinya. Hasil pengabdian ini relevan dengan hasil penelitian Setyaputri (2016) yang menggunakan permainan "roda pelangi" dalam bimbingan dan konseling yang meningkatkan efikasi diri siswa SMP. Demikian pula dengan hasil penelitian Leksana (2017) yang menerapkan permainan tradisional dalam layanan bimbingan kelompok bagi siswa sekolah dasar, yang memberikan efek terhadap peningkatan penyesuaian sosial siswa. Bahkan dengan pemberian permainan dalam penelitian Kusumaningtyas (2016) berfungsi sebagai terapi untuk mengatasi masalah siswa membolos. Karena dengan permainan dalam konseling kelompok dapat membantu menciptakan suasana rileks, menyenangkan, dapat membantu anggota saling mengakrabkan diri, yang akhirnya dapat membuat siswa berpengalaman dalam berbagi, saling menghargai, saling memberi tanggapan. Lestariani, et al. (2014) juga menyatakan bahwa dengan permainan dalam konseling kelompok dapat meningkatkan tingkat kreativitas anak usia dini.

\section{Kesimpulan}

Hasil penerapan permainan I've Got You dapat disimpulkan bahwa, partisipasi guru di SMA Negeri 1 Kurun yang menunjang program BK yakni dalam kegiatan sebagai berikut: (1) memperhatikan data siswa dalam membantu program BK.; (2) memperhatikan tingkah laku siswa di dalam kelas; (3) mengenal siswa yang memerlukan bantuan khusus; (4) mencatat pribadi siswa yang mempunyai kelainan tingkah laku dari siswa yang lainnya; (5) bekerja sama dengan petugas Bimbingan lainnya menyusun program BK; (6) membantu menyelenggarakan Bimbingan preventif kepada siswa.; (7) membantu memberikan layanan bimbingan kelompok kepada petugas Bimbingan mengenai keadaan siswa; (8) melengkapi inventarisasi siswa dengan data yang diperlukan; (9) mengirimkan siswa-siswa yang bersangkutan untuk datang kepada konselor; (10) menekankan implikasi kejujuran dari pada 
mata pelajaran yang mereka berikan; (11) tukar menukar informasi dengan konselor dan guru-guru lainnya; (12) memperkenalkan kepada siswa adanya pelayanan Bimbingan di sekolah dan menganjurkan untuk memanfaatkannya; (13) mengarahkan siswa-siswa agar studi semaksimal mungkin; (14) memperhatikan siswa-siswa dan mengenal mereka dengan baik; (15) membantu siswa dalam mengembangkan kebiasaan serta cara-cara belajar dan bekerja yang baik; (16) memperbincangkan perihal siswa dengan kepala sekolah dan konselor; dan (17) memperbincangkan perihal siswa dengan kepala sekolah dan konselor.

Beberapa kegiatan guru di sekolah yang perlu ditingkatkan partisipasinya yakni membantu menyelenggarakan bimbingan kelompok. Partisipasi guru di SMA Negeri 1 Kurun tinggi, dan pemanfaatan hasil permainan I've Got You adalah pada bidang pribadi dan sosial. Pemanfaatannya agar pada layanan bimbingan dan konseling selama ini bisa lebih menarik dan tidak membosankan dengan adanya permainan yang ditambahkan dalam setiap layanan, baik layanan bimbingan dan konseling, terkhusus pada layanan bimbingan kelompok bersifat pribadi siswa dan bisa bersosialisasi dengan teman sebayanya. Dapat juga memfasilitasi siswa memiliki kemampuan diri, rasa optimis, memiliki penilaian objektif, memiliki rasa tanggung jawab, memiliki cara berpikir rasional dan realistis yang baik terhadap suatu permasalahan yang dihadapinya.

\section{Daftar Pustaka}

Miller, M. H. \& Modigliani, F. 1961. Dividend Policy, Growth, and the Valuation of Shares. Journal of Business, 34 (4), 411-433.

Nazir, M. 1983. Metode Penelitian. Ghalia Indonesia.

Kusumaningtyas, A.S. 2016. Layanan konseling kelompok teknik play theraphi untuk mengatasi siswa membolos. Prosiding Seminar Nasional Bimbingan dan Konseling, Volume 1, Nomor 1, 49-57. Surabaya 28 Mei 2016, Universitas Negeri Surabaya.

Leksana, D.M. 2017. Bimbingan kelompok dengan teknik permainan tradisional untuk meningkatkan penyesuaian social. Jurnal of Childhood Education, 1(1), 14-20. http://dx.doi.org/10.30736/jce.v1i1.2.

Lestariani, K., Sulastri, M. \& Ambara, D.P. 2014. Efektifitas bimbingan kelompok melalui media permainan playdough untuk menignkatkan kreativitas. Jurnal Pendidikan Anak Usia Dini Undiksha, 2(1), http://dx.doi.org/10.23887/paud.v2i1.4381.

Sangalang, O.K. dan Nopi. 2016. Bimbingan Kelompok Dengan Menggunakan Teknik Musik dan Permainan (games) Untuk Meningkatkan Kecerdasan Emosional Siswa Kelas X SMA Negeri 1 Palangka Raya. Jurnal Pendidikan. Volume 17. Lembaga 
Penelitian Universitas Palangka Raya.

Senjaya, W. 2006. Strategi Pembelajaran. Jakarta: Kencana Prenada Media Group.

Setyaputri, N.Y. 2016. Media Permainan "Roda Pelangi" sebagai Alternatif Pilihan Media Bimbingan dan Konseling di Sekolah. Prosiding Seminar Nasional Bimbingan dan Konseling, Volume 1, Nomor 1, 146-150. Surabaya 28 Mei 2016, Universitas Negeri Surabaya.

Suwarjo \& Eliasa. 2011. 55 Permainan (Games) dalam Bimbingan dan Konseling. Yogyakarta: Paramitra Publishing.

SK Menteri Pada tanggal 15 Januari 1975 No. 008d/1975 dan 008e/1975

SK No. 84/1993

SK No. 118/1996

Kurikulum 2013 